Quality : Jurnal Kesehatan

Volume 14, Nomor 1 Tahun 2020

pISSN : 1978-4325, eISSN : 2655-2434, DOI: 10.36082/qjk.v14i1.92

\title{
SMART DENTAL BOX SEBAGAI MEDIA PENYULUHAN UNTUK PENINGKATAN PENGETAHUAN DAN PERILAKU KESEHATAN GIGI MULUT
}

\author{
Abral $^{1}$, Jusuf Kristianto ${ }^{2}$, Yeni Maryani ${ }^{3}$, Neni Setiawaty ${ }^{4}$, Rizki Sofian ${ }^{5}$ \\ 1,3,4 Jurusan Keperawatan, Politeknik Kesehatan Kemenkes Pontianak, Indonesia \\ ${ }^{2,5}$ Jurusan Keperawatan Gigi, Politeknik Kesehatan Kemenkes Jakarta I, Indonesia
}

\begin{abstract}
Info Artikel Abstrak
Genesis Naskah:

Submissions: $25-2-2020$

Revised: 09-3-2020, 25-5-

2020

Accepted: 25-5-2020

Kata Kunci:

Pengetahuan, perilaku, Smart Dental Box

Masalah kesehatan gigi dan mulut yang tinggi disebabkan oleh rendahnya perilaku menjaga kebersihan gigi dan mulut serta kurangnya pengetahuan tentang kesehatan gigi dan mulut, oleh karena itu dibutuhkan peningkatan upaya dalam mengatasi permasalahan tersebut salah satunya dengan peningkatan upaya promotif pada setiap lapisan masyarakat. Media promotif yang umum digunakan yaitu Flip Chat, Phantom dan Poster dengan metode ceramah dan demonstrasi. Dengan metode ceramah dan demonstrasi membuat anak menjadi pasif dan tidak mempunyai minat pada materi penyuluhan yang diberikan. Smart Dental Box merupakan alat peraga yang dirancang berbentuk seperti permainan yang lebih disenangi anak-anak. Alat ini akan mengeluarkan suara ketika tombol ditekan. Suara yang keluar berupa informasi yang berhubungan dengan bentuk dan fungsi gigi, kerusakan pada gigi, penyebab dan cara pencegahannya. Tujuan umum dalam penelitian ini adalah mengetahui pengaruh alat peraga Smart Dental Box sebagai media penyuluhan dalam meningkatkan pengetahuan dan perilaku kesehatan gigi dan mulut di SDN 01 Anjongan Kabupaten Mempawah. Penelitian ini dilakukan dengan pendekatan kuantitatif. Desain yang digunakan adalah quasi experiment dengan pola pre and post test without control. Tempat penelitian ini dilaksanakan di SDN 01 Anjongan Kabupaten Mempawah. Populasi adalah siswa kelas V di SDN 01 Anjongan Kabupaten Mempawah yang berjumlah 28. Sampel Penelitian ini menggunakan teknik total sampling. Hasil penelitian untuk pengetahuan, dari 28 responden didapatkan data responden dengan kategori baik dari 10 meningkat menjadi 23 reponden. Pada variabel perilaku, dengan kategori baik dari 1 meningkat menjadi 15 reponden. Hasil uji Paired Sample T-test pengetahuan dan perilaku, diperoleh nilai Sig. (2-tailed) 0,000 yang berarti lebih kecil dari 0,05 maka Ho ditolak.
\end{abstract}

\begin{tabular}{l} 
SMART DENTAL BOX MODEL AS A MEDIA OF EXTENSION FOR INCREASING \\
KNOWLEDGE AND BEHA VIOR MOUTH DENTAL HEALTH \\
\hline $\begin{array}{l}\text { Keywords: } \\
\text { Knowledge, behavior, } \\
\text { Smart Dental Box }\end{array} \quad \begin{array}{l}\text { Dental and oral health problems are caused by low dental and oral hygiene behavior and a lack } \\
\text { of knowledge about dental and oral health, therefore it is necessary to increase efforts in } \\
\text { overcoming these problems, one of which is by increasing promotive efforts at every level of } \\
\text { society. Promotive media that are commonly used are Flip Chat, Phantom and Poster with } \\
\text { lecture and demonstration methods. The lecture and demonstration methods make children } \\
\text { passive and have no interest in the counseling material provided. Smart Dental Box is a teaching } \\
\text { aid that is designed to be shaped like a game that is more loved by children. This tool will make a } \\
\text { sound when the button is pressed. The sound that comes out in the form of information relating to } \\
\text { the shape and function of teeth, damage to the teeth, causes and how to prevent them. }\end{array}$
\end{tabular}

(C) Poltekkes Kemenkes Jakarta I

J1. Wijaya Kusuma No. 47-48 Cilandak Jakarta Selatan, Indonesia email: jurnalquality@poltekkesjakarta1.ac.id

ISSN 2655-2434

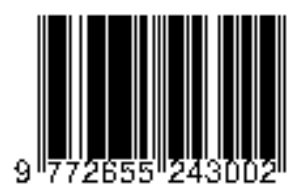


The general objective in this study was to determine the effect of Smart Dental Box teaching aids as an extension media in improving knowledge and behavior of dental and oral health in SDN 01 Anjongan District of Mempawah. This research was conducted with a quantitative approach. The design used is quasi experiment with pre and post test patterns without control. The place of this research was conducted at SDN 01 Anjongan District of Mempawah. The population is class $V$ students at SDN 01 Anjongan District of Mempawah, amounting to 28. Samples This study uses a total sampling technique. The results of research for knowledge, from 28 respondents obtained respondent data with good categories from 10 increased to 23 respondents. In the behavior variable, with a good category from 1 increased to 15 respondents. Paired Sample T-test for knowledge and behavior, the Sig. (2-tailed) 0,000, which means less than 0.05, then Ho is rejected.

\section{Korespondensi Penulis:}

Abral

Jurusan Keperawatan Gigi Politeknik Kesehatan Pontianak. 


\section{Pendahuluan}

Mengacu pada data hasil Riset Kesehatan Dasar (RISKESDAS) tahun 2018, prevalensi masalah kesehatan gigi dan mulut rata-rata di Indonesia adalah 57,6\% dengan perilaku menyikat gigi setiap hari adalah $94,7 \%$ dan hanya $2,8 \%$ yang berperilaku menyikat gigi dengan benar. Sebanyak 21 Provinsi di Indonesia mempunyai prevalensi masalah kesehatan gigi dan mulut di atas prevalensi nasional termasuk Provinsi Kalimantan Barat. Sekitar $60,5 \%$ penduduk di Kalimantan Barat memiliki permasalahan dengan kesehatan gigi dan mulutnya (Kementerian Kesehatan, 2018). Masalah kesehatan gigi dan mulut yang tinggi disebabkan oleh rendahnya perilaku menjaga kebersihan gigi dan mulut serta kurangnya pengetahuan tentang kesehatan gigi dan mulut, oleh karena itu dibutuhkan peningkatan upaya dalam mengatasi permasalahan tersebut salah satunya dengan peningkatan upaya promotif pada setiap lapisan masyarakat.

Upaya promotif dalam bidang kesehatan ditekankan pada meningkatkan kemampuan masyarakat untuk dapat melakukan upaya-upaya kesehatan secara mandiri melalui pendidikan kesehatan. Jadi upaya promotif pada hakekatnya merupakan salah satu bentuk proses pembelajarn, karena upaya tersebut bertujuan untuk merubah perilaku masyarakat menuju pola hidup sehat (Putu, 2012).

Penyuluhan kesehatan adalah kegiatan pendidikan kesehatan untuk mengembangkan pengertian yang benar dan sikap positif dari individu atau kelompok terhadap kesehatan dengan cara hidup sehat sebagai bagian dari cara hidupnya sehari-hari atas kesadaran dan kemauan sendiri. Penyuluhan yang dilakukan adalah dengan cara memberikan pesan, menanamkan keyakinan sehingga masyarakat tidak hanya tahu, sadar dan mengerti, tetapi juga mau dan bisa melakukan apa yang dianjurkan yang berhubungan dengan kesehatan. Penyuluhan kesehatan dapat dilakukan di sekolah-sekolah dan dapat juga dilakukan dilapangan (Machfoedz, 2005).

Keberhasilan penyuluhan kesehatan dalam upaya meningkatkan kesehatan, tergantung pada media yang digunakan oleh penyuluh untuk menciptakan peran serta masyarakat. Media akan membantu dalam pendidikan kesehatan asyarakat, karena pesan-pesan kesehatan dapat disampaikan secara lebih jelas sehingga sasaran (masyarakat) akan menerima pesan tersebut dengan jelas dan tepat (Putu, 2012) Media pendidikan kesehatan ada yang sudah disediakan sesuai dengan program masing-masing, namun ketersediaan media yang disalurkan oleh pemerintah sangat terbatas dan belum merata, maka dari itu para tenaga kesehatan diharapkan disamping mampu menggunakan media secara tepat dalam pendidikan kesehatan, diharapkan pula mampu merancang dan memproduksi media sederhana (Putu, 2012).

Umumnya kegiatan promotif seperti penyuluhan dilakukan oleh mahasiswa-mahasiswi Jurusan Keperawatan Gigi menggunakan media seperti Poster, Phantom Gigi dan Flip Chart. Pada saat melakukan penyuluhan seringkali penyuluh menggunakan metode ceramah dan demonstrasi, dimana dalam metode ini terdapat kelemahan (Taufik ,2007) yaitu terlalu monoton dan anak menjadi pasif karena anak hanya berperan sebagai pendengar dan penonton sehingga dapat menimbulkan kejenuhan dan mengganggu konsentrasi dalam melihat, mendengarkan dan menangkap materi penyuluhan yang diberikan hal ini menunjukkan kurangnya minat siswa-siswi terhadap penyuluhan menggunakan metode ceramah dan demonstrasi dengan media Flip Chart, Poster dan Phantom Gigi. Minimnya media yang digunakan untuk penyuluhan membuat peneliti mencoba menggunakan media yang berupa Smart Dental Box. Dimana alat ini dirancang berbentuk seperti permainan yang akan mengeluarkan suara berupa informasi tentang kesehatan gigi. Alat peraga seperti Smart Dental Box dalam pendidikan kesehatan gigi belum pernah dilakukan penelitian dan penyuluhan di Jurusan Keperawatan Gigi Poltekkes Kemenkes Pontianak sehingga membuat penulis tertarik untuk melakukan penelitian dengan media Smart Dental Box.

Berdasarkan latar belakang tersebut, peneliti ingin mengetahui "Pengaruh Alat Peraga Smart Dental Box Sebagai Media Penyuluhan Terhadap Pengetahuan dan Perilaku Kesehatan Gigi dan Mulut Siswa di SDN 01 Anjongan Kabupaten Mempawah" 


\section{Metodologi penelitian}

Jenis penelitian Penelitian ini akan dilakukan dengan pendekatan kuantitatif. Desain yang digunakan adalah Quasi experiment dengan pola pre and post test without control. Populasi dalam penelitian ini adalah siswa-siswi kelas V SDN 01 Anjongan yang berjumlah 26 responden. Sampel yang diambil dalam penelitian ini menggunakan teknik total sampling, yaitu teknik pengambilan sampel dimana jumlah sampel sama dengan jumlah populasi yaitu seluruh siswa-siswi kelas V SDN 01 Anjongan. Data berupa pengetahuan dan perilaku kesehatan gigi dan mulut dikumpulkan 21 dengan menggunakan lembar kuesioner.

Analisis data dilakukan dengan menggunakan uji Wilcoxon Signed Rank Test.

\section{Hasil}

Penelitian ini dilaksanakan di SDN 01 Anjongan yang berada di Kabupaten Mempawah. Jumlah keseluruhan responden yaitu siswa-siwi kelas V SDN 01 Anjongan yang berjumlah 28 orang dan teknik pengambilan sampel menggunakan teknik total sampling.

1. Karakteristik Jenis Kelamin Responden

Berikut ini adalah tabel jumlah responden

berdasarkan jenis kelamin :

Tabel 5.1 Distribusi Frekuensi Responden Berdasarkan Jenis Kelamin

\begin{tabular}{|l|c|c|}
\hline \multicolumn{1}{|c|}{ Jenis Kelamin } & Jumlah & Persentase (\%) \\
\hline Laki-laki & 8 & 28,6 \\
\hline Perempuan & 20 & 71,4 \\
\hline Total & 28 & 100 \\
\hline
\end{tabular}

Berdasarkan Tabel 5.1 dapat disimpulkan bahwa sebagian besar responden berjenis kelamin perempuan yakni sebanyak 21 orang $(75 \%)$.

2. Karakteristik Usia Responden

Berikut ini adalah tabel jumlah responden

berdasarkan usia :

Tabel 5.2 Distribusi Frekuensi Responden Berdasarkan Usia

\begin{tabular}{|l|c|c|}
\hline \multicolumn{1}{|c|}{ Usia } & Jumlah & Persentase (\%) \\
\hline 10 Tahun & 7 & 25 \\
\hline 11 Tahun & 15 & 54 \\
\hline 12 Tahun & 6 & 21 \\
\hline Total & 28 & 100 \\
\hline
\end{tabular}

(C) Poltekkes Kemenkes Jakarta I

Jl. Wijaya Kusuma No. 47-48 Cilandak Jakarta Selatan, Indonesia email: jurnalquality@poltekkesjakarta1.ac.id
Berdasarkan Tabel 5.2 dapat disimpulkan bahwa sebagian besar responden berusia 11 tahun yaitu sebanyak 15 orang (54\%).

3. Karakteristik Pengetahuan Responden

Berikut ini adalah tabel jumlah responden berdasarkan kategori pengetahuan sebelum dan sesudah dilakukan penyuluhan menggunakan alat peraga Smart Dental Box :

Tabel 5.3 Distribusi Frekuensi Responden Berdasarkan Pengetahuan Kesehatan Gigi dan Mulut Sebelum dan Sesudah Menerima Penyuluhan Menggunakan Smart Dental Box

\begin{tabular}{|l|c|c|c|c|}
\hline \multirow{2}{*}{$\begin{array}{c}\text { Kategori } \\
\text { Pengetah } \\
\text { uan }\end{array}$} & \multicolumn{2}{|c|}{ Delta Sebelum } & \multicolumn{2}{c|}{ Delta Sesudah } \\
\cline { 2 - 5 } & $\begin{array}{c}\text { Jumla } \\
\text { Baik }\end{array}$ & $\begin{array}{c}\text { Persentase } \\
(\%)\end{array}$ & $\begin{array}{c}\text { Jumla } \\
\mathrm{h}\end{array}$ & $\begin{array}{c}\text { Persentase } \\
(\%)\end{array}$ \\
\hline Cukup & 10 & 35,7 & 23 & 82,1 \\
\hline Kurang & 3 & 53,6 & 5 & 17,9 \\
\hline Total & 28 & 10,7 & 0 & 0 \\
\hline
\end{tabular}

Berdasarkan Tabel Distribusi 5.3 diketahui jumlah responden dengan kategori pengetahuan baik meningkat menjadi $23(82,1 \%)$ responden setelah dilakukan penyuluhan menggunakan alat peraga Smart Dental Box.

4. Karakteristik Perilaku Responden

Berikut ini adalah tabel jumlah responden berdasarkan kategori perilaku sebelum dan sesudah dilakukan penyuluhan menggunakan alat peraga Smart Dental Box :

Tabel 5.4 Distribusi Frekuensi Responden

Berdasarkan Perilaku Kesehatan Gigi dan

Mulut Sebelum dan Sesudah Menerima Penyuluhan Menggunakan Smart Dental Box

\begin{tabular}{|l|c|c|c|c|}
\hline Kategori & \multicolumn{2}{|c|}{ Delta Sebelum } & \multicolumn{2}{c|}{ Delta Sesudah } \\
\cline { 2 - 5 } Perilaku & $\begin{array}{c}\text { Jum } \\
\text { lah }\end{array}$ & $\begin{array}{c}\text { Persentas } \\
\text { e (\%) }\end{array}$ & $\begin{array}{c}\text { Jum } \\
\text { lah }\end{array}$ & $\begin{array}{c}\text { Persenta } \\
\text { se (\%) }\end{array}$ \\
\hline Baik & 1 & 3,6 & 15 & 53,6 \\
\hline Cukup & 1 & 3,6 & 13 & 46,4 \\
\hline Kurang & 26 & 92,9 & 0 & 0 \\
\hline Total & 28 & 100 & 28 & 100 \\
\hline
\end{tabular}

Berdasarkan Tabel Distribusi 5.4 diketahui jumlah responden dengan kategori perilaku baik meningkat menjadi $15(53,6 \%)$ responden setelah 
dilakukan penyuluhan menggunakan alat peraga Smart Dental Box.

\section{Analisis Statistik}

Berikut ini adalah tabel nilai rata-rata hasil penilaian pengetahuan dan perilaku kesehatan gigi dan mulut sebelum dan sesudah dilakukan penyuluhan menggunakan uji Paired Sampel T-test

Tabel 5.5 Distribusi Nilai Rata-Rata Delta Pengetahuan Sebelum dan Delta Sesudah Penyuluhan Menggunakan Smart Dental Box

\begin{tabular}{|l|c|}
\hline \multicolumn{1}{|c|}{ Komponen } & Rata-rata \\
\hline $\begin{array}{l}\text { Nilai pengetahuan sebelum } \\
\text { menerima penyuluhan }\end{array}$ & 11,14 \\
\hline $\begin{array}{l}\text { Nilai pengetahuan setelah } \\
\text { menerima penyuluhan }\end{array}$ & 12,75 \\
\hline
\end{tabular}

Berdasarkan Tabel 5.5 dapat disimpulkan bahwa terdapat Ada Pengaruh perbedaan nilai sebesar1.61 setelah diadakan penyuluhan dengan alat peraga Smart Dental Box dalam meningkatkan nilai rata-rata pengetahuan kesehatan gigi dan mulut responden yakni menjadi 12,75 setelah dilakukan penyuluhan menggunakan alat peraga Smart Dental Box.

Tabel 5.6 Distribusi Nilai Rata-RataPerilaku Delta Sebelum dan Delta Sesudah Penyuluhan Menggunakan Smart Dental Box

\begin{tabular}{|l|c|}
\hline \multicolumn{1}{|c|}{ Komponen } & Rata-rata \\
\hline $\begin{array}{l}\text { Nilai perilaku sebelum } \\
\text { menerima penyuluhan }\end{array}$ & 15,54 \\
\hline $\begin{array}{l}\text { Nilai perilaku setelah } \\
\text { menerima penyuluhan }\end{array}$ & 21,61 \\
\hline
\end{tabular}

Berdasarkan Tabel 5.6 dapat disimpulkan bahwa terdapat perbedaan nilai 6.07 setelah diberikan penyuluhan dengan alat peraga Smart Dental Box dalam meningkatkan nilai rata-rata perilaku kesehatan gigi dan mulut responden yakni menjadi 21,61 setelah dilakukan penyuluhan menggunakan alat peraga Smart Dental Box.

\section{Hasil Uji Paired Sample T-test}

Berikut ini adalah tabel hasil analisis statistik pengaruh alat peraga Smart Dental Box terhadap pengetahuan dan perilaku kesehatan gigi dan mulut sebelum dan sesudah penyuluhan menggunakan uji Paired Sample T-test :

Tabel 5.7 Hasil Uji Pengetahuan dan perilaku Kesehatan Gigi dan Mulut Sebelum dan Sesudah Penyuluhan Menggunakan Uji Paired Sample T-test

\begin{tabular}{|l|c|c|c|c|}
\hline Komponen & Mean & $\mathrm{t}$ & df & $\begin{array}{c}\text { Sig. } \\
(2- \\
\text { tailed })\end{array}$ \\
\hline $\begin{array}{l}\text { Nilai } \\
\begin{array}{l}\text { Pengetahuan } \\
\text { Sebelum - } \\
\text { Nilai } \\
\text { Pengetahuan } \\
\text { Setelah }\end{array}\end{array}$ & -1, & $-7,504$ & 27 & 0,000 \\
\hline $\begin{array}{l}\text { Nilai Perilaku } \\
\text { Sebelum - } \\
\text { Nilai Perilaku } \\
\text { Setelah }\end{array}$ & 6,071 & - & 27 & 0,000 \\
\hline
\end{tabular}

Berdasarkan Tabel 5.7 diperoleh nilai signifikansi 0,000 yang artinya kurang dari taraf signifikan 0,05, maka Ho ditolak. Artinya ada pengaruh alat peraga Smart Dental Box sebagai media penyuluhan terhadap peningkatan pengetahuan kesehatan gigi dan mulut siswa di SDN 01 Anjongan Kabupaten Mempawah. Pada tabel diperoleh nilai selisih rata-rata (mean) pengetahuan negatif yaitu $-1,607$, artinya rata-rata sebelum penyuluhan lebih rendah dari pada ratarata setelah penyuluhan. Pada perilaku diperoleh nilai signifikansi 0,000 yang artinya kurang dari taraf signifikan 0,05, maka Ho ditolak. Artinya ada pengaruh alat peraga Smart Dental Box sebagai media penyuluhan terhadap peningkatan perilaku kesehatan gigi dan mulut siswa di SDN 01 Anjongan Kabupaten Mempawah. Pada tabel diperoleh nilai selisih rata-rata (mean) perilaku negatif yaitu $-6,071$, artinya rata-rata sebelum penyuluhan lebih rendah dari pada rata-rata setelah penyuluhan.

\section{Pembahasan}

Penelitian ini dilaksanakan di SDN 01 Anjongan yang terletak di Kabupaten Mempawah dengan total responden sebanyak 28 orang yang terdiri dari $20(71,4 \%)$ perempuan dan $8(28,6 \%)$ laki-laki. Penelitian ini dilakukan untuk melihat 
pengaruh alat peraga Smart Dental Box terhadap pengetahuan kesehatan gigi dan mulut siswa di SDN 01 Anjongan Kabupaten Mempawah.

Penelitiian ini dilakukan dengan menggunakan lembar kuesioner desain Pre-test dan Post-test. Peneliti melakukan kalibrasi dengan tim yang sebelumnya sudah dijelaskan bagaimana cara menggunakan alat peraga Smart Dental Box. Pada saat penelitian, dari total responden yang berjumlah 28 orang dibagi menjadi 2 kelompok yang terdiri dari 14 orang dalam satu kelompok. Tiap masingmasing kelompok akan mendapatkan 2 orang pembimbing yang akan menjelaskan cara menggunakan alat peraga Smart Dental Box.

Sebelum memulai penyuluhan menggunakan alat peraga Smart Dental Box, peneliti akan membagikan lembar kuesioner kepada responden untuk mengetahui tingkat pengetahuan dan perilaku kesehatan gigi dan mulut responden sebelum diberikan penyuluhan menggunakan alat peraga Smart Dental Box. Setelah lembar kuesioner dibagikan kepada responden selanjutnya responden diinstruksikan untuk menjawab pertanyaan kuesioner. Setelah itu pembimbing akan memulai penyuluhan menggunakan alat peraga Smart Dental Box. Pembimbing pada setiap kelompok akan menjelaskan terlebih dahulu bagaimana cara penggunaan alat peraga Smart Dental Box. Pembimbing akan mencontohkan dengan cara menekan terlebih dahulu tombol pertama pada alat peraga. Selanjutnya tombol ditekan sendiri oleh reponden secara bergantian pada alat peraga Smart Dental Box dari tombol pertama pada gigi incisivus (gigi seri) sampai pada tombol terakhir yaitu tombol ketiga pada gigi molar (gigi geraham besar). Ketika setiap tombol ditekan akan mengeluarkan berbagai informasi tentang kesehatan gigi dan mulut dan responden akan mendengarkan setiap informasi sampai selesai. Setelah selesai, peneliti akan membagikan lagi lembar kuesioner kepada responden untuk mengetahui tingkat pengetahuan dan perilaku kesehatan gigi dan mulut setelah dilakukan penyuluhan menggunakan alat peraga Smart Dental Box.

Alat peraga yang digunakan dalam penelitian ini diberi nama Smart Dental Box karena alat ini memiliki kelebihan dari media penyuluhan lainnya yaitu bisa memberikan informasi kesehatan gigi dan mulut kepada responden dengan sendirinya.
Dimana biasanya pada media penyuluhan lainnya kebanyakan kita sebagai penyuluh yang menjelaskan informasi kesehatan gigi dan mulut kepada responden.

Pada umumnya alat peraga Smart Dental Box bisa digunakan untuk semua usia anak sekolah dasar, dari kelas I sampai kelas VI. Karena alat ini mempunyai bentuk yang unik dan menarik sehingga cocok untuk penyuluhan kesehatan gigi dan mulut pada anak usia sekolah dasar. Hanya saja pada saat melakukan penelitian terdapat beberapa kendala seperti terbatasnya waktu untuk melakukan penelitian karena anak sekolah pada saat itu sudah mau ulangan akhir semester dan libur lebaran, sehingga penelitian hanya dilakukan pada kelas $\mathrm{V}$ saja.

Penyuluhan menggunakan alat peraga Smart Dental Box merupakan salah satu upaya inovatif karena alat peraga ini merangkum berbagai informasi tentang kesehatan gigi dan mulut. Dimana pada tombol pertama setiap model gigi akan mengeluarkan informasi tentang bentuk dan fungsi gigi yang ada di depan tombol, tombol kedua pada setiap model gigi akan mengeluarkan informasi tentang bagian karies yang sering terjadi pada gigi yang ada di depan tombol dan tombol ketiga pada setiap model gigi akan menjelaskan tentang penyebab dan pengobatan karies gigi, makanan yang baik dan kurang baik untuk kesehatan gigi, cara menjaga kesehatan gigi dan mulut, dan yang terakhir tentang akibat bila tidak menyikat gigi. Alat peraga ini juga dapat digunakan untuk penyuluhan tanpa didampingi tenaga kesehatan.

Menggunakan media model gigi yang mengeluarkan suara saat penyuluhan kesehatan gigi, siswa dapat mengembangkan pengalamanpengalaman sensoris yang dapat membuat alat panca indera bekerja, misalnya melihat, mendengarkan dan meraba. Hal ini sejalan dengan pendapat Majid (2006) bahwa media penyuluhan kesehatan melalui media audiovisual memiliki beberapa keuntungan yaitu lebih menarik dan lebih mudah dipahami, dengan audiovisual seseorang dapat belajar sendiri, dapat diulang pada bagian tertentu yang perlu lebih jelas dan dapat menampilkan sesuatu yang lebih detail.

Hasil pada penelitian menunjukkan terjadi perubahan tingkat pengetahuan dan perilaku 
kesehatan gigi dan mulut pada responden setelah menerima penyuluhan menggunakan alat peraga Smart Dental Box. Adanya perubahan tingkat pengetahuan dan perilaku kesehatan gigi dan mulut sesudah dilakukan penyuluhan menandakan alat peraga Smart Dental Box berpengaruh terhadap pengetahuan dan perilaku kesehatan gigi dan mulut. Menurut Luluk 2014, pancaindera yang banyak menyalurkan pengetahuan ke otak adalah mata (kurang lebih $75 \%$ sampai $87 \%$ ), sedangkan $13 \%$ sampai $25 \%$ pengetahuan manusia diperoleh dan disalurkan melalui pancaindera yang lain. Media seharusnya mampu merangsang atau memasukkan informasi melalui berbagai indera. Semakin banyak yang dirangsang maka masuknya informasi akan semakin mudah. Media model gigi yang mengeluarkan suara memberikan rangsangan melalui mata dan telinga. Perpaduan saluran informasi melalui mata yang mencapai $75 \%$ dan telinga $13 \%$ akan memberikan rangsangan yang cukup baik sehingga dapat memberikan hasil yang optimal.

Berdasarkan data yang di dapat pada saat penelitian didapatkan 5 orang responden yang memiliki kategori pengetahuan cukup setelah dilakukan penyuluhan. Dari 5 responden tersebut terdapat 3 responden yang tidak mengalami peningkatan pengetahuan sebelum dan sesudah dilakukannya penyuluhan, dimana ketiga responden tersebut berjenis kelamin laki-laki. Menurut pengamatan pada saat penelitian hal ini terjadi karena ada beberapa responden yang asik sendiri bersama temannya ketika penyuluhan dilakukan. Menurut Herjulianti (2012) mengatakan bahwa pengetahuan kesehatan gigi dan mulut seseorang dipengaruhi oleh beberapa faktor diantaranya faktor internal dan eksternal. Faktor internal seperti pendidikan, minat dan sebagainya. Sedangkan faktor eksternal adalah tersedianya fasilitas kesehatan yang memadai.

Dari hasil uji analisis statistik menggunakan uji Paired Sample T-test tentang pengaruh alat peraga Smart Dental Box terhadap pengetahuan dan perilaku kesehatan gigi dan mulut sebelum dan sesudah dilakukan penyuluhan diperoleh nilai signifikansi 0,000 yang artinya lebih kecil dari 0,05 maka dapat disimpulkan adanya pengaruh alat peraga Smart Dental Box terhadap pengetahuan dan perilaku kesehatan gigi dan mulut siswa di SDN 01 Anjongan Kabupaten Mempawah.
Hal ini ditunjang dengan penelitian Luluk dan Erik (2014) yang berjudul pengaruh penyuluhan kesehatan dengan media video terhadap pengetahuan dan sikap personal hygiene siswa SDN 1 Kepek Pengasih Kulon Progo, yang menunjukkan bahwa pada pengukuran post test didapatkan nilai yang berpengetahuan baik 33 responden, cukup sebanyak 3 responden dan kurang tidak Hal ini pada penelitian tersebut samasama menggunakan media audiovisual. Bedanya visualisasi dari media video dapat bergerak, sedangkan visualisasi dari alat peraga Smart Dental Box adalah visual 3 dimensi yang tidak dapat bergerak.

Dengan demikian, penyuluhan dengan menggunakan alat peragamedia audiovisual berupa Smart Dental Box dapat menjadi sebuah alat peraga baru dalam penyuluhan kesehatan gigi dan mulut.

Kesimpulan

\section{Kesimpulan}

1. Pengetahuan siswa SDN 01 Anjongan Kabupaten Mempawah sebelum dilakukan penyuluhan sebagian cukup. Hanya saja masih ada 3 responden yang memiliki pengetahuan dengan kategori kurang. Nilai rata-rata pengetahuan responden sebelum dilakukan penyuluhan adalah 11,14, dimana kategori pengetahuan yang paling banyak yaitu kategori sedang.

2. Perilaku kesehatan gigi dan mulut siswa SDN 01 Anjongan Kabupaten Mempawah sebelum dilakukan penyuluhan sebagaian besar kurang. Hanya ada masing-masing 1 responden yang memiliki perilaku dengan kategori cukup dan baik. Nilai rata-rata perilaku responden sebelum dilakukan penyuluhan adalah 15,54, dimana kategori pengetahuan yang paling banyak yaitu kategori kurang.

3. Pengetahuan siswa SDN 01 Anjongan Kabupaten Mempawah setelah menerima penyuluhan mengalami perubahan yakni ditandai dengan tidak adanya responden yang memiliki pengetahuan dengan kategori kurang. Nilai rata-rata pengetahuan responden juga mengalami perubahan yakni meningkat menjadi 12,75 setelah diberi penyuluhan menggunakan Smart Dental Box, dimana kategori pengetahuan yang meningkat paling banyak yaitu kategori baik. 
4. Perilaku kesehatan gigi dan mulut siswa SDN 01 Anjongan Kabupaten Mempawah setelah dilakukan penyuluhan terjadi perubahan. Hal ini ditandai dengan meningkatnya jumlah responden pada kategori baik menjadi 15 responden. Nilai rata-rata perilaku responden juga mengalami perubahan yakni meningkat menjadi 21,61 setelah diberi penyuluhan menggunakan Smart Dental Box, dimana kategori pengetahuan yang meningkat paling banyak yaitu kategori baik.

5. Bedasarkan analisis statistik menggunakan uji Paired Sampel T-test terhadap pengetahuan dan perilaku kesehatan gigi dan mulut diperoleh nilai signifikansi yakni 0,000 yang artinya lebih kecil dari 0,05, maka Ho ditolak. Artinya ada pengaruh alat peraga Smart Dental Box sebagai media penyuluhan terhadap pengetahuan dan perilaku kesehatan gigi dan mulut siswa di SDN 01 Anjongan Kabupaten Mempawah.

\section{Saran}

1. Bagi sekolah diharapkan dapat memanfaatkan alat peraga Smart Dental Box sebagai sarana Hal ini khususnya tentang pengetahuan kesehatan gigi dan mulut.

2. Bagi Institusi DIII Keperawatan Gigi diharapkan dapat memanfaatkan dan memperbanyak alat peraga Smart Dental Box sebagai salah satu media dalam menyampaikan penyuluhan kesehatan gigi dan mulut.

3. Hasil penelitian ini diharapkan dapat digunakan sebagai pedoman bagi instansi kesehatan dan tenaga kesehatan, terutama keperawatan gigi untuk dapat meningkatkan pengetahuan kesehatan gigi dan mulut pada anak-anak melalui kegiatan promotif.

\section{Daftar Pustaka}

Depkes RI. (2004). Pusat Promosi Kesehatan Pengembangan Media Promosi Kesehatan. Jakarta

Herjulianti, Eliza dkk. (2012). Pendidikan

Kesehatan Gigi. Jakarta: EGC
Luluk dan Erik. (2014). Pengaruh Penyuluhan Kesehatan Dengan Media Video Terhadap Pengetahuan Dan Sikap Personal Hygiene Siswa SDN 1 Kepek Pengasih Kulon Progo. Program studi ilmu keperawatan sekolah tinggi ilmu kesehatan aisyiyah Yogyakarta.

Machfoedz. (2005). Pendidikan Kesehatan Bagian dari Promosi Kesehatan. Yogyakarta: Fitramaya

Majid A. (2006). Perencanaan Pembelajaran. Bandung : Remaja Rosdakarya

Maulana HDJ. (2009). Promosi Kesehatan. Jakarta: EGC

Putu, I. S., Dewa, I. Nyoman., (2012). Media Pendidikan Kesehatan. Yogyakarta : Graha Ilmu.p 